\title{
Analisis Tingkat Kesehatan Koperasi Di Kabupaten Kuningan Berdasarkan Peraturan Menteri Negara Koperasi dan Usaha Kecil dan Menengah Republik Indonesia Nomor 14/PER/M.UKM/XII/2009
}

\author{
Neni Nurhayati \\ olive_1902@yahoo.com \\ Rina Masruroh \\ Rinamasruroh83@gmail.com \\ Dosen Fakultas Ekonomi Universitas Kuningan
}

\begin{abstract}
Abstrak
Penelitian ini bertujuan untuk mengetahui tingkat kesehatan koperasi di Kabupaten Kuningan berdasarkan Peraturan Menteri Negara Koperasi dan Usaha Kecil dan menengah republik Indonesia Nomor 14/PER/M.UKM/XII/2009. Untuk mencapai tujuan tersebut, dilaksanakan metode penelitian deskripsi analitis dengan sumber data berupa data primer yaitu jawaban responden mengenai kelembagaan dan manajemen dan data sekunder yang bersumber dari Dinas Koperasi Usaha Kecil dan Menengah di Kabupaten Kuningan berupa data jumlah koperasi, laporan keuangan koperasi, laporan RAT koperasi dll. Populasi dalam penelitian ini adalah koperasi di Kabupaten Kuningan yang memiliki unit usaha simpan pinjam seperti KUD, KSU, KOPONTREN, KSP, dan KOPPAS. Teknik pengambilan sampel dengan menggunakan purposif sampling yaitu penentuan sampel dengan berdasarkan pertimbangan atau kriteria tertentu sehingga diproleh 40 sampel penelitian. Analisa data pada penelitian ini merujuk pada Peraturan Menteri Negara Koperasi dan Usaha Kecil dan Menengah Republik Indonesia Nomor : 14/PER/M.KUKM/XII/2009 yang mewakili tentang kondisi keuangan yang terdapat pada koperasi. Hasil penelitian menunjukan bahwa hasil perhitungan tujuh aspek yang telah dilakukan di Koperasi Kabupaten Kuningan, tingkat kesehatan koperasi pada tahun 2014 dari jumlah 40 koperasi, yang mendapatkan kategori predikat cukup sehat berjumlah 17 koperasi dan 23 koperasi mendapatkan predikat sehat. Sedangkan tahun 2015 dari jumlah 40 koperasi yang diteliti, 38 koperasi mendapatkan kategori cukup sehat sedangkan 2 koperasi mendapatkan kategori prediikat kurang sehat.
\end{abstract}

\section{PENDAHULUAN}

Koperasi merupakan bagian penting dalam sistem perekonomian bangsa,koperasi diyankini sebagai lembaga keuangan yang berpihak kepada golongan ekonomi lemah, dimana masayarakat golongan ekonomi lemah jumlah nya jauh lebih banyak dibandingkan dengan masyarakat golongan ekonomi menengah dan atas, sehingga tidak heran koperasi dianggap sebagai salah satu ujung tombak ekonomi kerakyatan yang diharapkan mampu mengurangi kesenjangan ekonomi, mengentaskan kemiskinan dan meningkatkan taraf ekonomi masyarakat. Hal ini sesuai dengan Pasal 3 UU Perkoperasian Nomor 25 tahun1992 bahwa pembangunan koperasi harus diarahkan kepada upaya memajukan kesejahteraan anggota pada khususnya dan masyarakat pada umumnya serta ikut membangun tatanan perekonomian dalam rangka mewujudkan masyarakat yang maju, adil dan makmur berlandaskan pancasila dan Undang-Undang Dasar 1945.

Namun dalam perkembangannya Koperasi di Indonesia dengan berbagai konsep ideal yang dibuat dan berbagai program pemerintah yang ditujukan untuk memberdayakan koperasi seperti KKop, Kredit Usaha Tani (KUT), pengalihan saham (satu persen) dari 
perusahaan besar ke koperasi, skim program KUK dari bank dan Kredit Ketahanan Pangan (KKP) yang merupakan kredit komersial dari perbankan, juga "paket program" dari Permodalan Nasional Madani (PNM) ternyata belum mampu melahirkan koperasi yang betul-betul tumbuh dan maju layaknya sebuah usaha besar.

Permasalahan yang dihadapi koperasi pun menjadi lebih beragam di era globalisasi ini, mulai dari masalah permodalan koperasi, dan masalah Regenerasi dalam pengurusan koperasi, manajemen koperasi, pengelolaan keuangan, SDM, Sarana dan prasarana dan sebagainya.

Tidak adanya contoh konkret koperasi yang betul-betul tumbuh dan maju menjadikan lembaga keuangan ini sepi peminat. Masyarakat lebih menyukai perbankan atau bahkan leasing dari pada berkoperasi. Terbukti berdasarkan data yang diperoleh dari Kementrian Koperasi dan UMKM RI pada bulan Juni tahun 2013 tercatat Jumlah anggota Koperasi di Indonesia sebanyak 34, 7 Juta orang. Jumlah ini memang meningkat bila dibandingkan dengan jumlah anggota koperasi tahun 2009 yaitu sebanyak 29,2 juta orang. Namun jika jumlah anggota koperasi tersebut dibandingkan dengan jumlah penduduk usia produktif di indonesia tahun 2010 sebanyak 156,9 Juta jiwa, maka anggota koperasi hanya 18,6 persen saja dari jumlah penduduk Indonesia usia produktif.

Hal ini merupakan bukti bahwa koperasi sebagai soko guru perekonomian bangsa kini bukanlah merupakan lembaga keuangan yang banyak diminati penduduk indonesia pada umumnya.

Permasalahan ini berakibat pada rendahnya Sumber Daya Manusia yang dimiliki Koperasi, berdampak pula pada rendahnya daya saing koperasi dan rendahnya kinerja keuangan koperasi, rendahnya tingkat kesehatan koperasi yang pada akhirnya pertumbuhan koperasi menjadi stagnan.
Permasalah koperasi di Indonesia secara umum juga terjadi di Kabupaten Kuningan. Kabupaten Kuningan yang notabene penduduknya bermata pencaharian sebagai petani, pedagang dan buruh memiliki potensi yang tinggi untuk berkoperasi dalam rangka mendukung aktivitas perekonomiannya, baik koperasi simpan pinjam, koperasi produksi, maupun koperasi serba usaha.

Namun berdasarkan data yang diperoleh dari Dinas KUKM Kabupaten Kuningan Tercatat bahwa Jumlah Koperasi di Kabupaten Kuningan secara keseluruhan berjumlah 532 Koperasi dengan Total Anggota Koperasi sebanyak 87,3 ribu orang baik anggota aktif maupun pasif. Jika dibandingkan dengan jumlah penduduk Kab. Kuningan yang berjumlah 1,1 juta jiwa tahun 2013, maka jumlah anggota koperasi di Kabupaten Kuningan hanya $7,8 \%$ nya saja. Hal ini merupakan bukti bahwa keberminatan masyarakat Kuningan terhadap koperasi masih rendah.

Sebenarnya penyebab utama permasalahan dalam koperasi adalah kurangnya rasa memiliki anggota terhadap koperasi terbukti banyak kasus yang terjadi terutama dalam koperasi simpan pinjam banyak anggota yang kurang atau bahkan tidak bertanggung jawab atas pinjamannya sehingga terjadi kemacetan dan menghambat kemajuan koperasi pada umumnya. Permasalahan yang terjadi dalam koperasi simpan pinjam ini juga ternyata terjadi dalam unit simpan pinjam koperasi lain, sehingga koperasi pada umumnya mengalami hambatan karena kemacetan pinjaman anggota.

Setelah dilakukan observasi dan analisa data diperoleh beberapa temuan diantaranya:

1. Dari Total 532 Koperasi di Kabupaten Kuningan hanya 137 Koperasi yang melaksanakan RAT atau sekitar $25,7 \%$ nya saja

2. Dari Total 532 koperasi di Kabupaten kuningan ternyata 
3. terdapat 107 atau $20,1 \%$ koperasi yang tidak aktif.

4. Terdapat 208 Koperasi Simpan Pinjam dan Koperasi yang memiliki unit simpan pinjam, dan ternyata yang masih aktif melakukan RAT 47 Koperasi atau sekitar $22,5 \%$ nya saja.

5. Kondisi ini menyebabkan kepercayaan dan minat masyarakat untuk berkoperasi menjadi turun

6. Turunnya minat masyarakat berdampak pada redahnya SDM yang dimiliki Koperasi

7. Rendahnya SDM yang dimiliki Koperasi berdampak pada rendahnya pengelolaan Koperasi

8. Rendahnya pengelolaan Koperasi berdampak pada rendahnya tingkat kesehatan Koperasi

9. Rendahnya tingkat kesehatan koperasi berdampak pada rendahnya daya saing koperasi.

10. Motivasi utama masyarakat berkoperasi adalah untuk memenuhi kebutuhan

hidup terutama untuk kebutuhan simpan pinjam.

Berdasarkan fakta dan data tersebut, dapat dianalisa bahwa tingkat kesehatan koperasi sangat berpengaruh terhadap daya saing koperasi yang menjadi penentu maju atau tidaknya koperasi. Jika Koperasi memiliki daya saing yang tinggi maka minat masyarakat untuk berkoperasi pun akan meningkat, sehingga koperasi dapat memiliki SDM yang lebih unggul dampaknya daya saing koperasi akan terus meningkat. Maka faktor utama yang harus diperbaiki untuk

meningkatkan daya saing koperasi adalah dengan meningkatkan kesehatan koperasi.

Selanjutnya karena mayoritas minat masyarakat menjadi anggota koperasi adalah untuk kebutuhan simpan pinjam, maka dalam penelitian ini penulis memfokuskan penelitian pada koperasi simpan pinjam.
Oleh karena ini penulis mencoba membuat penelitian tentang analisa tingkat kesehatan koperasi di Kabupaten Kuningan sebagai salah satu penentu daya saing koperasi, dengan judul " Analisis Tingkat Kesehatan koperasi Di Kabupaten Kuningan berdasarkan Peraturan Menteri Negara Koperasi dan Usaha Kecil dan Menengah Republik Indonesia Nomor 14/PER/M.UKM/XII/2009”.

Penelitian ini sangat penting dilakukan karena melalui penelitian ini akan diperoleh data yang akurat tentang tingkat kesehatan koperasi di kabupaten Kuningan, sehingga setelah diperoleh data yang akurat akan dapat diperoleh solusi dan langkah terbaik untuk memecahkan masalah yang dihadapi koperasi saat ini.

\section{KERANGKA BERFIKIR}

Tidak adanya contoh konkret koperasi yang betul-betul tumbuh dan maju menjadikan lembaga keuangan ini sepi peminat. Kondisi ini menyebabkan kepercayaan dan minat masyarakat untuk berkoperasi menjadi turun. Turunnya minat masyarakat berdampak pada redahnya SDM yang dimiliki Koperasi. Rendahnya SDM yang dimiliki koperasi ini berdampak pada rendahnya sistem pengelolaan koperasi yang kemudian berdampak pada tingkat kesehatan koperasi dan rendahnya kinerja keuangan koperasi, hal tersebut menjadikan koperasikoperasi di Kabupaten Kuningan tidak memiliki daya saing yang tinggi yang pada akhirnya pertumbuhan koperasi menjadi stagnan bahkan tidak aktif kembali.

Sebenarnya penyebab utama permasalahan dalam koperasi adalah kurangnya rasa memiliki anggota terhadap koperasi terbukti banyak kasus yang terjadi terutama dalam koperasi simpan pinjam banyak anggota yang kurang atau bahkan tidak bertanggung jawab atas pinjamannya sehingga terjadi kemacetan dan menghambat kemajuan koperasi pada umumnya. 
Berdasarkan fakta dan data di Kabupaten Kuningan, dapat dianalisa bahwa tingkat kesehatan koperasi sangat berpengaruh terhadap daya saing koperasi yang menjadi penentu maju atau tidaknya koperasi. Jika Koperasi memiliki daya saing yang tinggi maka minat masyarakat untuk berkoperasi pun akan meningkat, sehingga koperasi dapat memiliki SDM yang lebih unggul dampaknya daya saing koperasi akan terus meningkat. Maka faktor utama yang harus diperbaiki untuk meningkatkan daya saing koperasi adalah dengan meningkatkan kesehatan koperasi. Jika digambarkan maka kerangka berfikir dari penelitian ini adalah:

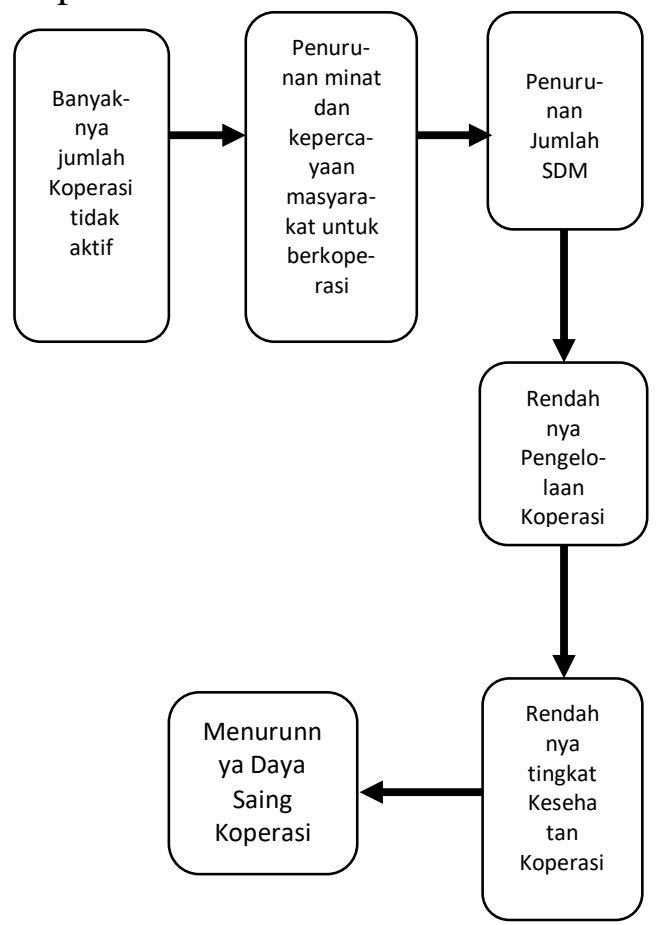

\section{METODE PENELITIAN}

Metode penelitian digunakan adalah metode deskriptif analitis yaitu metode yang bertujuan mendeskripsikan atau memberikan gambaran terhadap suatu objek penelitian yang diteliti melalui sampel atau data yang telah terkumpul dan membuat kesimpulan yang berlaku umum. (Sugiyono, 2009).

Penelitian akan dilakukan pada Koperasi-koperasi di Kabupaten Kuningan yang melakukan unit simpan pinjam seperti KUD, KSU, KOPONTREN, KSP dan KOPPAS.
Rencana Penelitian ini dilakukan dalam jangka waktu 1 (satu) tahun.

Populasi dalam penelitian ini adalah koperasi di Kabupaten Kuningan yang memiliki unit usaha simpan pinjam seperti KUD, KSU, KOPONTREN, dan KSP. Dikarenakan adanya keterbatasan penelitian baik waktu, biaya, maupun tenaga maka penulis mengambil sampel penelitian dengan menggunakan teknik purposif sampling yang menurut Sugiono (2010: 85) yaitu penentuan sampel dengan pertimbangan tertentu. Sampel tersebut diambil dengan kriteria-kriteria atau pertimbangan sebagai berikut:

1) Koperasi melakukan unit usaha Simpan Pinjam

2) Koperasi aktif

3) Melakukan RAT

4) Menyajikan Laporan Keuangan

Tahunan pada tahun 2014-2015

Berdasarkan kriteria tersebut diatas maka sampel yang digunakan dalam penelitian ini berjumlah 40 koperasi.

Data primer adalah data yang diperoleh atau dikumpulkan oleh peneliti langsung dari sumbernya baik berupa lisan maupun tulisan. Data primer dalam penelitian ini adalah jawaban responden mengenai kelembagaan dan manajemen.

Data sekunder adalah data yang telah dikumpulkan oleh lembaga pengumpul data dan sudah diolah serta dipublikasikan kepada masyarakat pengguna data. Data sekunder yang dikumpulkan unuk penelitian ini bersumber dari Dinas Koperasi Usaha Kecil dan Menengah di Kabupaten Kuningan berupa data jumlah koperasi, laporan keuangan koperasi, laporan RAT koperasi dll.

Teknik pengumpulan data dalam penelitian ini menggunkan:

1. Riset Kepustakaan (Library Research)

Teori dan alat analisis diperoleh dari buku-buku, diktat, literatur dan referensi-referensi yang relevan dan berkaitan dengan penelitian ini.

2. Riset Lapangan (Field Research) 
Pengumpulan

data

untuk penelitian ini juga dilakukan dengan cara mencatat dari dokumen maupun arsip yang diperoleh dari lembaga atau instansi yang berhubungan dengan penelitian ini. Telaah dokumen dilakukan terhadap arsip serta dokumen yang berkaitan dengan penelitian ini, diantaranya data koperasi, laporan RAT, dan laporan keuangan koperasi di

Kabupaten Kuningan.

Cara yang dilakukan penulis dalam mengumpulkan data yaitu:

\section{a. Observasi}

Riset dilakukan dengan cara melakukan pencatatan data yang diperoleh berupa laporan RAT dan laporan keuangan.

b. Wawancara

Riset dilakukan dengan mengadakan tanya jawab langsung kepada ketua Koperasi untuk memperoleh data yang akurat.

Analisa data pada penelitian ini merujuk pada Peraturan Menteri Negara Koperasi dan Usaha Kecil dan Menengah Republik Indonesia Nomor : 14/PER/M.KUKM/XII/2009 yang mewakili tentang kondisi keuangan yang terdapat pada koperasi yang terdiri dariaspek permodalan, kualitas aktiva produktif, manajemen, efisiensi, likuiditas, kemandirian dan pertumbuhan, serta aspek jati diri koperasi.

\section{HASIL PENELITIAN}

Analisis data yang digunakan dalam penelitian ini adalah Penelitian Acuan Patokan (PAP) yang berpedoman pada Keputusan Peraturan Menteri Negara Koperasi dan UKM No. 14/Per/M.KUKM/XII/2009 tentang Pedoman Penilaian Tingkat Kesehatan Koperasi dan Unit Simpan Pinjam Koperasi, yang kemudian dinilai tingkat ketimpangan atau kesenjangannya. Dimana, penilaian tersebut mencakup tujuh aspek permodalan, aspek kualitas aktiva produktif, aspek manajemen, aspek efisensi, aspek likuiditas, aspek kemandirian dan pertumbuhan koperasi serta jatidiri koperasi.

Selain penelitian tingkat kesehatan koperasi di Kabupaten Kuningan, penelitian ini juga menganalisis perkembangan tingkat kesehatan koperasi di Kabupaten Kuningan dari tahun 2014-2015 dengan menggunakan analisis trend.

Analisis trend dimaksudkan untuk mengukur maupun mengetahui kecenderungan perkembangan koperasi di Kabupaten Kuningan yanng terjadi apakah menaik atau menurun. Kecenderungan yang menaik atau menurun diukur dengan menjumlahkan skor tujuh aspek penilaian pada koperasi di Kabupaten Kuningan yang telah dinilai. 
Rekapitulasi Tingkat Kesehatan KSP di Kabupaten Kuningan Tahun 2014

\begin{tabular}{|c|l|c|c|c|c|c|c|c|c|c|}
\hline NO & NAMA KOPERASI & $\begin{array}{c}\text { PERMODA } \\
\text { LAN } \\
\cdot\end{array}$ & $\begin{array}{c}\text { KSALIT } \\
\text { AKTIVA } \\
\text { PRODU } \\
\text { KTIF }\end{array}$ & $\begin{array}{c}\text { MANAJ } \\
\text { EMEN }\end{array}$ & $\begin{array}{c}\text { EFISIEN } \\
\text { SI }\end{array}$ & $\begin{array}{c}\text { LIKUI } \\
\text { DITAS }\end{array}$ & $\begin{array}{c}\text { KEMANDI } \\
\text { RIAN DAN } \\
\text { PERTUMB } \\
\text { UHAN }\end{array}$ & $\begin{array}{c}\text { JATIDIRI } \\
\text { KOPERASI }\end{array}$ & JUMLAH & PREDIKAT \\
\hline & $\begin{array}{l}\text { Koperasi Serba } \\
\text { Usaha }\end{array}$ & & & & & & & & & \\
\hline 1 & KOPEKA & 10,50 & 16,00 & 11,90 & 7,00 & 7,50 & 15,50 & 7,00 & 75,40 & $\begin{array}{l}\text { CUKUP } \\
\text { SEHAT }\end{array}$ \\
\hline 2 & $\begin{array}{l}\text { PRIMKOPKAR } \\
\text { Perum Perhutani }\end{array}$ & 10,80 & 19,00 & 12,55 & 8,00 & 7,50 & 18,50 & 10,00 & 86,35 & SEHAT \\
\hline & $\begin{array}{l}\text { KPRI Guru } \\
\text { Cibingbin- }\end{array}$ & & & & & & & & & \\
\hline 3 & Cibeureum & 9,90 & 16,50 & 11,55 & 10,00 & 7,50 & 18,50 & 9,25 & 83,20 & SEHAT \\
\hline 4 & Koperasi Linggajati & 10,50 & 16,50 & 10,75 & 6,50 & 3,75 & 18,50 & 6,50 & 73,00 & $\begin{array}{l}\text { CUKUP } \\
\text { SEHAT }\end{array}$ \\
\hline 5 & $\begin{array}{l}\text { KSU Makmur } \\
\text { Kencana }\end{array}$ & 4,50 & 18,00 & 10,85 & 8,00 & 5,00 & 18,50 & 10,00 & 74,85 & $\begin{array}{l}\text { CUKUP } \\
\text { SEHAT }\end{array}$ \\
\hline 6 & Ksu Maju Jaya & 15,00 & 23,00 & 11,15 & 9,00 & 3,75 & 15,50 & 10,00 & 87,40 & SEHAT \\
\hline 7 & KP-RI Sehat & 10,20 & 15,50 & 9,40 & 10,00 & 6,25 & 11,00 & 7,00 & 69,35 & $\begin{array}{l}\text { CUKUP } \\
\text { SEHAT }\end{array}$ \\
\hline
\end{tabular}

\begin{tabular}{|c|c|c|c|c|c|c|c|c|c|c|}
\hline 8 & KPRI BUMELA & 10,50 & 17,50 & 9,90 & 10,00 & 6,25 & 15,50 & 7,00 & 76,65 & $\begin{array}{l}\text { CUKUP } \\
\text { SEHAT }\end{array}$ \\
\hline 9 & $\begin{array}{l}\text { Koperasi Dharma } \\
\text { Wanita Ciremai }\end{array}$ & 9,30 & 21,00 & 12,75 & 10,00 & 7,50 & 20,00 & 10,00 & 90,55 & SEHAT \\
\hline 10 & KPRI KGH & 10,20 & 21,50 & 11,75 & 8,00 & 7,50 & 19,25 & 10,00 & 88,20 & SEHAT \\
\hline 11 & Eka Praya & 10,50 & 23,00 & 11,50 & 8,00 & 5,00 & 14,75 & 10,00 & 82,75 & SEHAT \\
\hline 12 & Karya Nugraha & 12,00 & 14,75 & 12,50 & 3,00 & 3,75 & 14,75 & 4,75 & 65,50 & $\begin{array}{l}\text { CUKUP } \\
\text { SEHAT }\end{array}$ \\
\hline 13 & Sarasi & 6,30 & 18,00 & 12,00 & 7,50 & 8,75 & 17,00 & 8,50 & 78,05 & $\begin{array}{l}\text { CUKUP } \\
\text { SEHAT }\end{array}$ \\
\hline 14 & Saluyu & 10,80 & 20,50 & 12,05 & 5,00 & 3,75 & 17,75 & 10,00 & 79,85 & $\begin{array}{l}\text { CUKUP } \\
\text { SEHAT } \\
\end{array}$ \\
\hline 15 & $\begin{array}{l}\text { Kopkar RS Wijaya } \\
\text { Kusumah }\end{array}$ & 14,40 & 19,50 & 11,05 & 6,00 & 5,00 & 20,00 & 10,00 & 85,95 & SEHAT \\
\hline 16 & KPRI Guru Cilimus & 11,40 & 20,00 & 10,15 & 10,00 & 5,00 & 15,50 & 10,00 & 82,05 & SEHAT \\
\hline 17 & Kopkar Asy-Syifa & 8,40 & 18,50 & 11,25 & 9,00 & 7,50 & 13,25 & 7,00 & 74,90 & $\begin{array}{l}\text { CUKUP } \\
\text { SEHAT }\end{array}$ \\
\hline 18 & Mega Mulia & 10,20 & 20,50 & 13,60 & 7,50 & $\begin{array}{c}10,0 \\
0\end{array}$ & 17,00 & 9,25 & 88,05 & SEHAT \\
\hline 19 & Laras Ati & 10,50 & 8,00 & 12,40 & 8,00 & 3,75 & 18,50 & 4,75 & 65,90 & $\begin{array}{l}\text { CUKUP } \\
\text { SEHAT }\end{array}$ \\
\hline 20 & $\begin{array}{l}\text { Primkop Kartika } \\
\text { Arya Kamuning }\end{array}$ & 9,30 & 20,00 & 11,55 & 8,00 & 7,50 & 14,75 & 10,00 & 81,10 & SEHAT \\
\hline 21 & KPRI Guru Jalaksana & 12,60 & 19,50 & 10,30 & 8,00 & 7,50 & 13,25 & 7,00 & 78,15 & $\begin{array}{l}\text { CUKUP } \\
\text { SEHAT }\end{array}$ \\
\hline 22 & KSP Mekar Jaya & 5,10 & 23,00 & 10,65 & 10,00 & 7,50 & 14,75 & 10,00 & 81,00 & SEHAT \\
\hline 23 & $\begin{array}{l}\text { Koperasi } \\
\text { Pengayoman }\end{array}$ & 11,40 & 20,50 & 11,85 & 7,00 & 7,50 & 7,00 & 8,50 & 73,75 & $\begin{array}{l}\text { CUKUP } \\
\text { SEHAT }\end{array}$ \\
\hline & $\begin{array}{l}\text { Koperasi Simpan } \\
\text { Pinjam }\end{array}$ & & & & & & & & & \\
\hline 24 & Marga Mulia & 10,50 & 20,00 & 10,90 & 7,00 & 5,00 & 18,50 & 10,00 & 81,90 & SEHAT \\
\hline 25 & KPDK & 10,50 & 17,00 & 10,60 & 7,00 & 7,50 & 17,75 & 10,00 & 80,35 & SEHAT \\
\hline 26 & $\begin{array}{l}\text { Primkoptama } \\
\text { Cilimus }\end{array}$ & 10,50 & 18,50 & 11,95 & 7,50 & 7,50 & 18,50 & 10,00 & 84,45 & SEHAT \\
\hline 27 & $\begin{array}{l}\text { Primkoptama } \\
\text { Sriwangi }\end{array}$ & 12,00 & 21,00 & 11,65 & 7,00 & 3,75 & 16,00 & 10,00 & 81,40 & SEHAT \\
\hline 28 & $\begin{array}{l}\text { KSP Kary. Objek } \\
\text { Wisata Linggarjati }\end{array}$ & 10,50 & 16,00 & 11,15 & 10,00 & 7,50 & 15,25 & 10,00 & 80,40 & SEHAT \\
\hline 29 & $\begin{array}{l}\text { KOKAR Pemdagri } \\
\text { Kab. Kuningan }\end{array}$ & 11,40 & 19,50 & 10,40 & 9,00 & 7,50 & 15,50 & 10,00 & 83,30 & SEHAT \\
\hline 30 & Mitra Makmur & 7,80 & 19,00 & 11,00 & 5,00 & $\begin{array}{c}15,0 \\
0\end{array}$ & 13,25 & 10,00 & 81,05 & SEHAT \\
\hline
\end{tabular}


Analisis..... ( Neni Nurhayati \& Rina Masruroh )

\begin{tabular}{|l|l|c|c|c|c|c|c|c|c|c|}
31 & Kuningan & 10,50 & 20,50 & 11,15 & 10,00 & 7,50 & 14,75 & 7,00 & 81,40 & SEHAT \\
\hline & $\begin{array}{l}\text { Kop Pegawai } \\
\text { Pengadilan Negeri } \\
\text { Kng }\end{array}$ & 7,80 & 20,00 & 12,15 & 8,00 & $\begin{array}{c}15,0 \\
0\end{array}$ & 17,75 & 10,00 & 90,70 & SEHAT \\
\hline 33 & Wana Marga Mukti & 5,70 & 15,50 & 13,40 & 9,00 & 6,25 & 17,75 & 10,00 & 77,60 & $\begin{array}{c}\text { CUKUP } \\
\text { SEHAT }\end{array}$ \\
\hline 34 & Hibanjah & 5,70 & 21,00 & 13,35 & 7,00 & $\begin{array}{c}15,0 \\
0\end{array}$ & 7,75 & 10,00 & 79,80 & $\begin{array}{c}\text { CUKUP } \\
\text { SEHAT }\end{array}$ \\
\hline & Koperasi Unit Desa & & & & & & & & & \\
\hline 35 & Suka Mekar & 12,00 & 18,50 & 13,45 & 7,00 & 6,25 & 14,00 & 4,75 & 75,95 & $\begin{array}{c}\text { CUKUP } \\
\text { SEHAT }\end{array}$ \\
\hline 36 & Setia Murni & 3,00 & 20,00 & 13,75 & 8,00 & $\begin{array}{c}10,0 \\
0\end{array}$ & 15,50 & 10,00 & 80,25 & SEHAT \\
\hline 37 & Sindang Agung & 7,80 & 22,50 & 11,50 & 7,00 & $\begin{array}{c}10,0 \\
0\end{array}$ & 16,25 & 10,00 & 85,05 & SEHAT \\
\hline 38 & Bangkit Abadi & 10,50 & 19,50 & 11,80 & 8,00 & 3,75 & 8,50 & 10,00 & 72,05 & $\begin{array}{c}\text { CUKUP } \\
\text { SEHAT }\end{array}$ \\
\hline
\end{tabular}

\begin{tabular}{|c|c|c|c|c|c|c|c|c|c|c|}
\hline & KOPONTREN & & & & & & & & & \\
\hline 39 & $\mathrm{Al}$ Istiqomah & 12,60 & 20,00 & 13,35 & 8,00 & 5,00 & 15,50 & 9,25 & 83,70 & SEHAT \\
\hline 40 & Al Mishbah & 5,10 & 20,00 & 12,35 & 7,00 & 7,50 & 7,75 & 10,00 & 69,70 & $\begin{array}{l}\text { CUKUP } \\
\text { SEHAT }\end{array}$ \\
\hline
\end{tabular}

Sumber :Perhitungan Rasio-rasio Aspek Penilaian Tingkat Kesehatan Koperasi

Kabupaten Kuningan Tahun 2014-2015

Tabel 5.24.

Rekapitulasi Tingkat Kesehatan KSP di Kabupaten

Kuningan Tahun 2015

\begin{tabular}{|c|c|c|c|c|c|c|c|c|c|c|}
\hline $\begin{array}{l}\text { NO } \\
.\end{array}$ & $\begin{array}{l}\text { NAMA } \\
\text { KOPERASI }\end{array}$ & $\begin{array}{l}\text { PERMODA } \\
\text { LAN }\end{array}$ & \begin{tabular}{|c} 
KUALI \\
T \\
AS \\
AKTIV \\
A \\
PRODU \\
KTIF
\end{tabular} & $\begin{array}{l}\text { MANAJ } \\
\text { EMEN }\end{array}$ & $\begin{array}{r}\text { EFISIE } \\
\mathbf{N} \\
\text { SI }\end{array}$ & $\begin{array}{l}\text { LIKUI } \\
\text { DITAS }\end{array}$ & $\begin{array}{l}\text { KEMANDI } \\
\text { RIAN DAN } \\
\text { PERTUMB } \\
\text { UHAN }\end{array}$ & $\begin{array}{c}\text { JATIDIRI } \\
\text { KOPERASI }\end{array}$ & JUMLAH & $\begin{array}{c}\text { PREDIKA } \\
T\end{array}$ \\
\hline & $\begin{array}{l}\text { Koperasi Serba } \\
\text { Usaha }\end{array}$ & & & & & & & & & \\
\hline 1 & KOPEKA & 10,50 & 17,00 & 14,20 & 8,00 & 3,75 & 5,50 & 1,75 & 60,70 & $\begin{array}{l}\text { CUKUP } \\
\text { SEHAT }\end{array}$ \\
\hline 2 & $\begin{array}{l}\text { PRIMKOPKAR } \\
\text { Perum Perhutani }\end{array}$ & 11,40 & 18,50 & 13,65 & 6,00 & 3,75 & 9,25 & 4,75 & 67,30 & $\begin{array}{l}\text { CUKUP } \\
\text { SEHAT }\end{array}$ \\
\hline 3 & $\begin{array}{l}\text { KPRI Guru } \\
\text { Cibingbin- } \\
\text { Cibeureum }\end{array}$ & 9,90 & 16,50 & 12,75 & 10,00 & 3,75 & 8,50 & 4,75 & 66,15 & $\begin{array}{l}\text { CUKUP } \\
\text { SEHAT }\end{array}$ \\
\hline 4 & $\begin{array}{l}\text { Koperasi } \\
\text { Linggajati } \\
\end{array}$ & 10,50 & 19,00 & 12,15 & 5,50 & 3,75 & 6,25 & 4,00 & 61,15 & $\begin{array}{l}\text { CUKUP } \\
\text { SEHAT }\end{array}$ \\
\hline 5 & $\begin{array}{l}\text { KSU Makmur } \\
\text { Kencana }\end{array}$ & 4,35 & 19,00 & 11,15 & 10,00 & 3,75 & 9,25 & 4,75 & 62,25 & $\begin{array}{l}\text { CUKUP } \\
\text { SEHAT }\end{array}$ \\
\hline 6 & Ksu Maju Jaya & 15,00 & 22,00 & 11,40 & 9,50 & 3,75 & 9,25 & 4,75 & 75,65 & $\begin{array}{l}\text { CUKUP } \\
\text { SEHAT }\end{array}$ \\
\hline 7 & KP-RI Sehat & 10,80 & 16,00 & 11,25 & 10,00 & 3,75 & 5,50 & 1,75 & 59,05 & $\begin{array}{l}\text { KURANG } \\
\text { SEHAT }\end{array}$ \\
\hline 8 & KPRI BUMELA & 10,50 & 18,50 & 12,60 & 9,00 & 3,75 & 5,50 & 1,75 & 61,60 & $\begin{array}{l}\text { CUKUP } \\
\text { SEHAT }\end{array}$ \\
\hline 9 & $\begin{array}{l}\text { Koperasi Dharma } \\
\text { Wanita Ciremai }\end{array}$ & 9,30 & 21,00 & 12,10 & 10,00 & 3,75 & 10,00 & 8,25 & 74,40 & $\begin{array}{l}\text { CUKUP } \\
\text { SEHAT }\end{array}$ \\
\hline 10 & KPRI KGH & 10,20 & 18,50 & 11,40 & 7,00 & 3,75 & 10,00 & 4,75 & 65,60 & $\begin{array}{l}\text { CUKUP } \\
\text { SEHAT }\end{array}$ \\
\hline 11 & Eka Praya & 10,50 & 22,50 & 11,90 & 8,00 & 3,75 & 9,25 & 4,75 & 70,65 & $\begin{array}{l}\text { CUKUP } \\
\text { SEHAT }\end{array}$ \\
\hline 12 & Karya Nugraha & 10,50 & 15,75 & 13,50 & 5,00 & 3,75 & 9,25 & 4,75 & 62,50 & $\begin{array}{l}\text { CUKUP } \\
\text { SEHAT }\end{array}$ \\
\hline 13 & Sarasi & 7,80 & 18,00 & 13,10 & 8,00 & $\begin{array}{c}11,2 \\
5 \\
\end{array}$ & 7,00 & 3,25 & 68,40 & $\begin{array}{l}\text { CUKUP } \\
\text { SEHAT }\end{array}$ \\
\hline 14 & Saluyu & 6,90 & 18,00 & 12,90 & 8,00 & 3,75 & 7,75 & 4,75 & 62,05 & $\begin{array}{l}\text { CUKUP } \\
\text { SEHAT }\end{array}$ \\
\hline & $\begin{array}{l}\text { Kopkar RS } \\
\text { Wijaya }\end{array}$ & & & & & & & & & KURANG \\
\hline
\end{tabular}




\begin{tabular}{|c|c|c|c|c|c|c|c|c|c|c|}
\hline 15 & \begin{tabular}{|l} 
Kusumah \\
\end{tabular} & 12,00 & 20,50 & 11,00 & 3,00 & 2,00 & 6,00 & 2,00 & 56,50 & SEHAT \\
\hline 16 & $\begin{array}{l}\text { KPRI Guru } \\
\text { Cilimus }\end{array}$ & 12,00 & 19,50 & 11,30 & 10,00 & 3,75 & 10,00 & 4,75 & 71,30 & $\begin{array}{l}\text { CUKUP } \\
\text { SEHAT }\end{array}$ \\
\hline 17 & Kopkar Asy-Syifa & 8,40 & 18,50 & 11,20 & 9,00 & 3,75 & 7,75 & 4,75 & 63,35 & \begin{tabular}{|l} 
CUKUP \\
SEHAT \\
\end{tabular} \\
\hline 18 & Mega Mulia & 9,60 & 21,00 & 13,90 & 9,00 & 3,75 & 7,75 & 4,00 & 69,00 & \begin{tabular}{|l} 
CUKUP \\
SEHAT \\
\end{tabular} \\
\hline 19 & Laras Ati & 10,50 & 12,75 & 13,15 & 8,00 & 3,75 & 9,25 & 4,75 & 62,15 & \begin{tabular}{|l} 
CUKUP \\
SEHAT \\
\end{tabular} \\
\hline 20 & $\begin{array}{l}\text { Primkop Kartika } \\
\text { Arya Kamuning }\end{array}$ & 10,50 & 19,00 & 13,10 & 7,00 & 3,75 & 8,50 & 4,00 & 65,85 & \begin{tabular}{|l} 
CUKUP \\
SEHAT
\end{tabular} \\
\hline 21 & $\begin{array}{l}\text { KPRI Guru } \\
\text { Jalaksana }\end{array}$ & 12,60 & 19,50 & 12,60 & 9,00 & 3,75 & 5,50 & 4,75 & 67,70 & $\begin{array}{l}\text { CUKUP } \\
\text { SEHAT }\end{array}$ \\
\hline 22 & KSP Mekar Jaya & 5,10 & 23,00 & 12,35 & 9,00 & 3,75 & 7,75 & 4,75 & 65,70 & $\begin{array}{l}\text { CUKUP } \\
\text { SEHAT } \\
\end{array}$ \\
\hline 23 & $\begin{array}{l}\text { Koperasi } \\
\text { Pengayoman }\end{array}$ & 12,60 & 21,00 & 13,35 & 10,00 & 3,75 & 8,50 & 4,75 & 73,95 & $\begin{array}{l}\text { CUKUP } \\
\text { SEHAT }\end{array}$ \\
\hline & $\begin{array}{l}\text { Koperasi Simpan } \\
\text { Pinjam }\end{array}$ & & & & & & & & & \\
\hline 24 & Marga Mulia & 12,00 & 21,00 & 13,05 & 6,50 & 3,75 & 9,25 & 4,75 & 70,30 & $\begin{array}{l}\text { CUKUP } \\
\text { SEHAT } \\
\end{array}$ \\
\hline 25 & KPDK & 10,50 & 17,00 & 12,20 & 6,00 & 3,75 & 7,00 & 4,75 & 61,20 & $\begin{array}{l}\text { CUKUP } \\
\text { SEHAT }\end{array}$ \\
\hline 26 & $\begin{array}{l}\text { Primkoptama } \\
\text { Cilimus }\end{array}$ & 9,90 & 18,50 & 13,00 & 7,50 & 3,75 & 8,50 & 4,75 & 65,90 & $\begin{array}{l}\text { CUKUP } \\
\text { SEHAT }\end{array}$ \\
\hline 27 & $\begin{array}{l}\text { Primkoptama } \\
\text { Sriwangi }\end{array}$ & 12,00 & 21,00 & 13,10 & 5,00 & 3,75 & 7,00 & 3,25 & 65,10 & $\begin{array}{l}\text { CUKUP } \\
\text { SEHAT } \\
\end{array}$ \\
\hline 28 & $\begin{array}{l}\text { KSP Kary. Objek } \\
\text { Wisata Linggarjati }\end{array}$ & 10,50 & 17,50 & 11,40 & 9,00 & 3,75 & 6,00 & 4,75 & 62,90 & $\begin{array}{l}\text { CUKUP } \\
\text { SEHAT }\end{array}$ \\
\hline 29 & $\begin{array}{l}\text { KOKAR Pemdagri } \\
\text { Kab. Kuningan }\end{array}$ & 12,00 & 19,50 & 11,40 & 8,00 & 3,75 & 8,50 & 4,75 & 67,90 & $\begin{array}{l}\text { CUKUP } \\
\text { SEHAT }\end{array}$ \\
\hline 30 & Mitra Makmur & 8,40 & 19,00 & 12,15 & 5,00 & 3,75 & 7,00 & 4,75 & 60,05 & $\begin{array}{l}\text { CUKUP } \\
\text { SEHAT }\end{array}$ \\
\hline 31 & $\begin{array}{l}\text { KOPMI Kab. } \\
\text { Kuningan }\end{array}$ & 10,50 & 20,50 & 13,05 & 10,00 & 3,75 & 6,25 & 1,75 & 65,80 & $\begin{array}{l}\text { CUKUP } \\
\text { SEHAT } \\
\end{array}$ \\
\hline 32 & $\begin{array}{l}\text { Kop Pegawai } \\
\text { Pengadilan Negeri } \\
\text { Kng }\end{array}$ & 12,60 & 20,00 & 12,60 & 9,00 & 3,75 & 8,50 & 4,75 & 71,20 & $\begin{array}{l}\text { CUKUP } \\
\text { SEHAT } \\
\end{array}$ \\
\hline 33 & $\begin{array}{l}\text { Wana Marga } \\
\text { Mukti }\end{array}$ & 6,90 & 16,00 & 12,90 & 9,00 & 3,75 & 9,25 & 4,75 & 62,55 & $\begin{array}{l}\text { CUKUP } \\
\text { SEHAT } \\
\end{array}$ \\
\hline 34 & Hibanjah & 6,30 & 20,50 & 13,10 & 10,00 & 3,75 & 7,75 & 8,25 & 69,65 & $\begin{array}{l}\text { CUKUP } \\
\text { SEHAT } \\
\end{array}$ \\
\hline & $\begin{array}{l}\text { Koperasi Unit } \\
\text { Desa } \\
\end{array}$ & & & & & & & & & \\
\hline 35 & Suka Mekar & 12,00 & 17,00 & 13,85 & 7,00 & 6,25 & 7,75 & 4,75 & 68,60 & $\begin{array}{l}\text { CUKUP } \\
\text { SEHAT }\end{array}$ \\
\hline 36 & Setia Murni & 0,30 & 19,50 & 14,75 & 8,00 & 6,25 & 7,75 & 4,75 & 61,30 & $\begin{array}{l}\text { CUKUP } \\
\text { SEHAT }\end{array}$ \\
\hline 37 & Sindang Agung & 7,80 & 22,50 & 12,85 & 9,00 & 6,25 & 8,50 & 4,75 & 71,65 & $\begin{array}{l}\text { CUKUP } \\
\text { SEHAT } \\
\end{array}$ \\
\hline 38 & Bangkit Abadi & 10,50 & 20,00 & 11,80 & 7,00 & 3,75 & 5,50 & 4,75 & 63,30 & $\begin{array}{l}\text { CUKUP } \\
\text { SEHAT } \\
\end{array}$ \\
\hline & KOPONTREN & & & & & & & & & \\
\hline 39 & Al Istiqomah & 12,60 & 20,50 & 14,00 & 7,00 & 6,25 & 7,75 & 5,75 & 73,85 & $\begin{array}{l}\text { CUKUP } \\
\text { SEHAT }\end{array}$ \\
\hline 40 & Al Mishbah & 5,10 & 19,00 & 13,50 & 6,50 & 3,75 & 7,75 & 8,25 & 63,85 & $\begin{array}{l}\text { CUKUP } \\
\text { SEHAT }\end{array}$ \\
\hline
\end{tabular}

Sumber :Perhitungan Rasio-rasio Aspek Penilaian Tingkat

Kesehatan Koperasi Kabupaten Kuningan Tahun 2014-2015

\section{PEMBAHASAN}

1. Penilaian Tingkat Kesehatan

Koperasi di Kabupaten

Kuningan Tahun 2014-2015
Penilaian aspek permodalan koperasi di Kabupaten Kuningan dengan cara melakukan perhitungan dan penyekoran terhadap tiga rasio, diantaranya adalah rasio modal sendiri terhadap total assets, rasio modal sendiri terhadap pinjaman 
diberikan yang berisiko, dan rasio kecukupan modal sendiri. Dari hasil perhitungan dan penyekoran yang telah dilakukan, aspek permodalan koperasi di Kabupaten Kuningan pada tahun 2014-2015 memperoleh rata-rata jumlah skor untuk tahun 2014 sebesar 9.71 dan tahun 2015 sebesar 9.78 (lampiran) artinya aspek permodalan koperasi yang ada di Kabupaten Kuningan mengalami kenaikan, maka dari itu setiap koperasi perlu mempertahankan bahkan meningkatkan lagi jumlah permodalan dari tahun ke tahun, supaya kegiatan koperasi bisa berkembang dengan baik dan berjalan dengan lancar.

Penilaian aspek kualitas aktiva produktif koperasi di Kabupaten Kuningan dilakukan dengan cara melakukan perhitungan dan penyekoran terhadap empat rasio, diantaranya adalah rasio volume pinjaman pada anggota terhadap volume pinjaman yang diberikan, rasio risiko pinjaman bermasalah terhadap pinjaman yang diberikan, rasio cadangan risiko terhadap risiko pinjaman yang diberikan, rasio pinjaman yang berisiko terhadap pinjaman yang diberikan. Dari hasil perhitungan dan penyekoran yang telah dilakukan, aspek kualitas aktiva produktif koperasi di Kabupaten Kuningan pada tahun 2014-2015 memperoleh rata-rata skor untuk tahun 2014 sebesar 18.97 dan tahun 2015 sebesar 19.10 (lampiran). Artinya koperasi di Kabupaten Kuningan memiliki komponen harta yang cukup sehat atau cukup baik dalam menghasilkan pendapatan, akan tetapi, dari keseluruhan hasil perhitungan rasio-rasio dalam aspek kualitas aktiva produktif, perlu diminimalisir lagi besarnya pinjaman bermasalah yang ada dan perlu memperbesar lagi dana yang dialokasikan untuk cadangan risiko kredit.
Penilaian Aspek manajemen koperasi di Kabupaten Kuningan dilakukan dengan cara melakukan perhitungan dan penyekoran terhadap lima komponen, diantaranya adalah komponen manajemen umum, manajemen kelembagaan, manajemen permodalan, manajemen aktiva, dan manajemen likuiditas. Dari hasil perhitungan dan penyekoran yang telah dilakukan, aspek manajemen koperasi di Kabupaten Kuningan pada tahun 2014-2015 memperoleh ratarata jumlah skor untuk tahun 2014 sebesar 11.68 dan tahun 2015 sebesar 12.62 (lampiran). Artinya koperasi di Kabupaten Kuningan memiliki pengelolaan kegiatan koperasi yang cukup sehat, akan tetapi karena belum adanya visi, misi, tujuan dan SOP serta SOM dari setiap masing-masing koperasi dengan beberapa kategori belum maksimal, membuat koperasi menjadi kurang terencana dalam pelaksanaan kegiatan usahanya. Alangkah baiknya apabila kekurangan tersebut segera dilengkapi dan diatur dengan baik sehingga tujuan dari koperasi bisa tercapai.

Penilaian aspek efisiensi koperasi di Kabupaten Kunigan dilakukan dengan cara melakukan perhituangan dan penyekoran terhadap tiga rasio, diantaranya adalah rasio biaya operasional pelayanan terhadap partisipasi bruto, rasio beban usaha terhadap SHU kotor, dan rasio efisiensi pelayanan. Dari hasil perhitungan dan penyekoran tersebut, aspek efisiensi koperasi di Kabupaten Kuningan pada tahun 2014-2015 memperoleh rata-rata jumlah skor untuk tahun 2014 sebesar 7.88 dan tahun 2015 sebesar 7.94 (lampiran). Artinya koperasi di Kabupaten Kuningan masih cukup sehat dalam memberikan efisiensi pelayanan kepada anggotanya atau bisa dikatakan cukup baik, akan tetapi hal ini perlu ditingkatkan kembali guna untuk pengembangan koperasi kearah yang lebih baik lagi, kemudian perlu 
diminimalisir lagi besarnya beban usaha yang dikeluarkan oleh koperasi, supaya assets yang dikelola oleh setiap koperasi bisa memberikan efisiensi pelayanan kepada anggotanya terutama dalam penggunaan assets koperasi.

Penilaian aspek likuditas koperasi di Kabupaten Kuningan dilakukan dengan cara melakukan perhitungan dan penyekoran terhadap dua rasio, daiantaranya adalah rasio kas dan bank terhadap kewajiban lancar dan rasio pinjaman yang diberikan terhadap dana yang diterima. Dari hasil perhitungan dan penyekoran tersebut, aspek likuiditas koperasi pada tahun 2014-2015 memperoleh rata-rata jumlah skor untuk tahun 2014 sebesar 7.13 dan untuk tahun 2015 sebesar 4.14 (lampiran) artinya sebagian koperasi di Kabupaten Kuningan tergolong masih belum mampu dalam memenuhi kewajiban jangka pendeknya. Oleh karena itu, koperasi perlu meningkatkan lagi kelancaran pengambilan pinjaman yang telah disalurkan dengan cara mempertegas aturan pengembalian pinjaman.

Penilaian aspek kemandirian dan pertumbuhan koperasi di Kabupaten Kuningan dilakukan dengan cara melakukan perhitungan dan penyekoran terhadap tiga rasio, diantaranya adalah rasio rentabilitas assets, rasio rentabilitas modal sendiri dan rasio kemandirian operasional. Dari hasil perhitungan dan penyekoran tersebut, aspek kemandirian dan pertumbuhan koperasi pada tahun 2014-2015 memperoleh rata-rata jumlah skor untuk tahun 2014 sebesar 15.48 dan tahun 2015 sebesar 7.83 (lampiran). Artinya koperasi di Kabupaten Kuninagn sudah cukup sehat atau cukup baik dalam kemampuannya menghasilkan laba dan kemandirian modal. Akan tetapi dari keseluruhan hasil perhitungan rasio-rasio dalam aspek kemandirian dan pertumbuhan, perlu ditingkatkan lagi modal sendiri yang dimiliki serta mengoptimalkan kegiatan usaha selain simpan pinjam dan lain-lain, supaya mendatangkan keuntungan yang lebih besar.

Penilaian aspek jatidiri koperasi pada koperasi di Kabupaten Kuningan dilakukan dengan cara melakukan perhitungan dan penyekoran terhadap dua rasio, diantaranya adalah rasio partisipasi bruto dan rasio promosi ekonomi anggota. Dari hasil perhitungan dan penyekoran tersebut, aspek jati diri kopersi di Kabupaten Kuningan pad tahun 2014-2015 memperoleh rata-rata jumlah skor tahun 2014 sebesar 8.94 dan tahun 2015 sebesar 4.54 (lampiran). Artinya koperasi di Kabupaten Kuningan dalam kemampuannya memberikan manfaat ekonomi kepada anggotanya masih cukup baik untuk tahun 2014 sedangkan untuk tahun 2015 kurang baik. Oleh karena itu, perlu ditingkatkan lagi kontribusi partisipasi bruto anggotanya.

\section{Perkembangan Tingkat Kesehatan Koperasi di Kabupaten Kuningan Tahun 2014-2015}

Tingkat kesehatan koperasi dinilai berdasarkan tujuh aspek yang sudah ditetapkan pada Peraturan Menteri Negara Koperasi dan UKM Tahun 2009. Dimana, peniliannya mencakup tujuh aspek diantaranya adalah aspek permodalan, aspek kualitas aktiva produktif, aspek manajemen, aspek efisiensi, aspek likuditas, aspek kemandirian dan pertumbuhan serta aspek jatidiri koperasi.

Dari hasil perhitungan tujuh aspek yang telah dilakukan pada koperasi di Kabupaten Kuningan yang berjumlah 40 koperasi sebagai data sampel pada tahun 2014 berada pada kategori Predikat Koperasi Cukup Sehat berjumlah 17 koperasi dan predikat koperasi Sehat berjumlah 23 koperasi. 
Sedangkan pada tahun 2015 dari data sampel diperoleh kategori predikat cukup sehat 38 koperasi dan predikat kurang sehat berjumlah 2 koperasi. Artinya koperasi di Kabupaten Kuningan pada tahun 2014-2015 mengalami sedikit penurunan, sehingga perlu ditingkatkan kembali dan diperbaiki kesehatan koperasinya dari ketujuh aspek yang sudah ditentukan oleh Peraturan Kementrian Negara Koperasi dan UKM tahun 2009, guna kedepannya atau dari tahun-ketahun koperasi di Kabupaten Kuningan akan berubah kearah yang lebih baik dan berkembang dengan pesat dengan tujuan mensejahterakan perekonomian serta peningkatan pertumbuhan ekonomi khususnya di Kabupaten Kuningan.

\section{KESIMPULAN}

Berdasarkan analisis data yang telah dilakukan berkaitan dengan tingkat kesehatan koperasi di Kabupaten Kuningan, maka dapat diambil kesimpulan sebagai berikut :

1. Aspek permodalan koperasi di Kabupaten Kuningan pada tahun 2014-2015 memiliki permodalan yang sehat.

2. Aspek kualitas aktiva produktif koperasi di Kabupaten Kuningan pada tahun 2014-2015 mempunyai kualitas harta yang cukup sehat.

3. Aspek manajemen koperasi di Kabupaten Kuningan pada tahun 2014-2015 memiliki pengelolaan kegiatan koperasi yang cukup sehat.

4. Aspek efesiensi koperasi di Kabupaten Kuningan pada tahun 2014-2015 dalam memberikan efisiensi pelayanan kepada anggotanya dinilai cukup baik.

5. Aspek likudititas koperasi di Kabupaten Kuningan pada tahun 2014-2015 dikatakan cukup sehat atau cukup baik.

6. Aspek kemandirian dan pertumbuhan koperasi di Kabupaten Kuningan pada tahun 2014-2015 dalam menghasilkan laba dan kemandirian permodalan sudah cukup baik.

7. Aspek jatidiri kopersi pada koperasi di Kabupaten Kuningan pada tahun 2014-2015 dalam memberikan manfaat ekonomi kepada anggotanya dinilai cukup baik.

8. Dari hasil perhitungan tujuh aspek yang telah dilakukan di Koperasi Kabupaten Kuningan, tingkat kesehatan koperasi pada tahun 2014 dari jumlah 40 koperasi, yang mendapatkan kategori predikat cukup sehat berjumlah 17 koperasi dan 23 koperasi mendapatkan predikat sehat. Sedangkan tahun 2015 dari jumlah 40 koperasi yang diteliti, 38 koperasi mendapatkan kategori cukup sehat sedangkan 2 koperasi mendapatkan kategori prediikat kurang sehat.

\section{Daftar Pustaka}

Data Koperasi Dinas KUKM Kab. Kuningan tahun 2015

http://koperasi.kulonprogokab.go.id/article14-jumlah-koperasi-2013-sudahmelebihi-target-2014.html http://kuningankab.bps.go.id/LinkTabel Statis/view/id/9

Peraturan Menteri Negara Koperasi dan Usaha Kecil dan Menengah Republik Indonesia Nomor 14/PER/M.KUKM/XII/2009

Rudianto, 2010. Akuntansi Koperasi. Erlangga.

Sugiyono, 2009. Metode Penelitian Bisnis. Alfabeta Bandung. Sugiyono, 2010.

Metode Penelitian Bisnis. Alfabeta Bandung. http://yunitasaraswati.blogspot.com/2014/11/ masalah-masalah-yang- timbul-dalam. html 